\title{
BEHAVIOR AND HIVISTI SEROPREVALENCE SURVEY AMONG MIGRANT LABORS, THEIR WIVES AND OTHER WOMEN WITH STI SYNDROMES IN KANCHANPUR
}

\author{
Bohara MS'1, Dhungana GP1', Thakuri BC² \\ ${ }^{1}$ Department of Microbiology, Shree Siddhanath Science Campus Mahendranagar, Nepal \\ 2 Shree Siddhanath Science Campus Mahendranagar, Nepal
}

\begin{abstract}
Introduction: Migrant people were high risk group in acquiring HIV and others STI. Nepal is facing rapid increase in prevalence among high-risk groups such as sex workers, injection drug users and migrants. Western part of Nepal faces the same threat. The objective of the study is to measure HIVISTI status in-migrant labors, their wives and women with STD syndromes in Kanchanpur.

Methodology: A cross-sectional analytical study was carried out in migrant labors, their wives and women with STD syndromes in year 2009 at Department of Microbiology, Siddhanath Science Campus, Mahendranagar, Kanchanpur.

Results: Out of 208 migrant workers, wife/husband of migrant workers, children of migrant workers $18(8.5 \%)$ were found HIV positive and $40(19 \%)$ had different STI. The HIV acquiring is highly associated with STIs co- infected patients $(p<0.01)$. Fifty-three $(26 \%)$ respondents always used condom and 47 (23\%) did not use. A large number $43(21 \%)$ had prostitute as sexual partner and majority of $130(64 \%)$ were stricted to single sexual partner but $49(24 \%)$ had 2 to 4 sexual partners and $24(12 \%)$ had more than 4 sexual partners.

Conclusion: It was found that migrant people were at high risk of acquiring HIV and other STIs. Male migrants may engage in having sexual relationship with multiple partners. Adult migrant had HIV infection. The HIV infection was significantly associated with other STIs.
\end{abstract}

Key words: Migrants, High-risk groups, Sexual-contact, Kanchanpur

\section{INTRODUCTION}

AIDS (Acquired Immunodeficiency Syndrome), an infectious fatal disease caused by Human Immunodeficiency Virus (HIV) is spreading in an unpredictable rate causing huge human and socioeconomic loss. ${ }^{1}$ Globally, an estimated 33.4 million (31.1million-35.8 million) people are

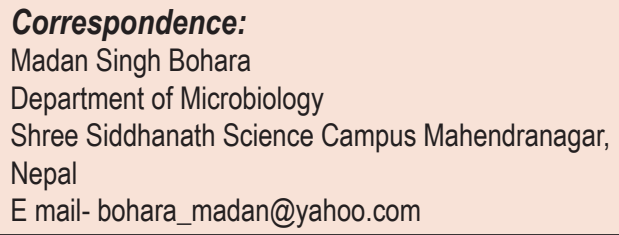

currently living with HIV according to UNAIDS. In 2008, an estimated 2.7 million (2.4 million-3.0 million) people were newly infected with $\mathrm{HIV}^{2}$ While the estimated number of PLHA in Nepal is more than 75,000 , the recorded number, as reported by National centre of AIDS and STI control (NCASC), is 14,320 (as of July 2009). ${ }^{3}$

Among different high risk groups, the migrant labor constitutes the significant proportion in certain areas of Nepal, out of the total HIV cases in Nepal, 32, 341 $(46 \%)$ seasonal labor migrant were estimated for HIV positive. ${ }^{4}$ Mobility or migration must not itself be a risk factor for HIV, but could create conditions and circumstances, that made the migrant workers 
vulnerable to HIV/ AIDS. What these people have in common is that they work in low paid, unskilled jobs in hostile environment and their vulnerability rose from their need for company, intimacy and sex. infection HI In Nepal, 2 million male migrant workers regularly cross the border faciliting the spread of the virus, similarly thousands of migrant workers cross the borders from neighboring in search of work to Nepal. ${ }^{5}$ Currently, migration is one of the major social factors for the rapid spread of HIV in Nepal. Several bio- behavioral as well as HIV seroprevalance studies conducted in Far Western region of Nepal during different time intervals documented HIV prevalence of and inferred that this region was major hot spot of HIV population, mainly due to high rate of migration. ${ }^{6}$

STIs are among the top five disease categories and about one third of STIs globally occur among people younger than 25 years of age. ${ }^{7}$ It has been well established that women with STD syndromes are at higher risk of HIV infection. Firstly, the mode of infection of HIV and other STIs are same. Secondly, it is easier for HIV to enter and cause infection because of dysfunction of first line of defense mechanism (for e.g. ulceration of the skin). Moreover, its transmission is 3-9 times more in patients with STD syndromes as compared to general population. ${ }^{8}$

Based on these data it has been realized that migrant population, especially labor migrant to India was recognized with high degree of confidence. Hence, this study focused on this special population" Migrant labor" who are being at risk of the contracting and spreading this dreaded infection and disease HIV/AIDS. Kanchanpur's low economic status, illiteracy and high rate of migration along with the frequent unsafe practice with female sex workers in Indian cities make this population high vulnerable to acquiring HIV infection. So, the behavior and seroprevalence study in this population not only documents the exact prevalence of HIV seroprevalence and other STIs in this population but also help to control the transmission of HIV in general population through provision of comprehensive care and support service in collaboration with other INGOs/hospitals located in this district. In Kanchanpur no specific study on the labor migrants is done to generate surveillance data regarding the different types of STIs including HIVIAIDS.

\section{METHODOLOGY}

This cross-sectional community based study was carried out by department of Microbiology, Shree Siddhanath Science Campus, Mahendranagar, Kanchanpur, during March to June 2009. Before the initiation of study ethical clearance was approved from the campus administration. The study was carried out on 208 patients who were self reported as migrant, their wives and others (belongs to migrant family). To make the sample more representative and community oriented, they were selected from different sites of Kanchanpur district: antiretroviral therapy centre of Mahakali Zonal Hospital, Nepal National Social Welfare Association (NNSWA) VCT center, HIVIAIDS camp at Jhalari VDC and Dodhara VDC. Migrant's people were enrolled in the study because they were highly vulnerable to HIVISTIs. Once the patients were identified, the verbal and written consent was taken from each patient. Then, a prestructured standard questionnaire was administered to each patient on the following topics: Sexual behavior and knowledge on HIVISTI transmission was reported. These data were kept confidential. Then, blood samples, cervical swabs, endocervical swabs from women and additional urethral swabs from male were collected. Privacy was strictly maintained during sample collection. The patients were selected for diagnosis of different STIs on the basis of vaginal discharge, pain in lower abdomen, chancre on genital organs and pus discharged from urethra. In case of STIs women were not eligible if they were pregnant, reported missed periods or had given birth in the previous six weeks, because of greater susceptibility to vaginal candidiasis at these times. On the day of examination, women were excluded if they were menstruating, because 
menstrual blood would interfere with the laboratory tests. Unmarried girls were barred to speculum examination, because it was not deemed culturally appropriate for them.

The collected specimens were transported to Microbiology Laboratory, Siddhanath Science Campus, Kanchanpur and specimen processing was done as per standard Microbiological operating procedure for HIV testing and others STIs investigation.

The data generated from interview and lab investigation were entered into Statistical Package for Social Sciences 11.5 version and then analyzed to get the required information related to objectives of the study.

\section{RESULTS}

The study was carried out on 208 migrant, wives of migrant and others (belongs to migrant family) visiting to ART centre of Mahakali Zonal Hospital, Nepal National Social Welfare Association VCT center, HIVIAIDS camp at Jhalari VDC and Dodhara VDC (Table 1).

Table 1. Age and sex distribution of patients tested for HIV and others STIs

\begin{tabular}{|l|r|r|r|}
\hline Age group & \multicolumn{1}{l|}{ Male } & Female & \multicolumn{1}{l|}{ Total } \\
\hline $\begin{array}{l}0-14 \\
\text { years }\end{array}$ & $1(2.5 \%)$ & $2(1.2 \%)$ & $3(1.5 \%)$ \\
\hline $\begin{array}{l}15-29 \\
\text { years }\end{array}$ & $14(35.0 \%)$ & $86(51.2 \%)$ & $100(48 \%)$ \\
\hline $\begin{array}{l}30-49 \\
\text { years }\end{array}$ & $22(55.0 \%)$ & $77(45.8 \%)$ & $99(47.5 \%)$ \\
\hline$\geq 50$ years & $3(7.5 \%)$ & $3(1.8 \%)$ & $6(3 \%)$ \\
\hline Total & $40(100 \%)$ & $168(100 \%)$ & $208(100 \%)$ \\
\hline
\end{tabular}

Out of 208 patients $40(19 \%)$ were male and $168(81 \%)$ were female. The highest numbers of population were in age group $15-29$ years $(48 \%)$. Similar to $30-49$ yrs $(47.5 \%)$. Followed by age group $30-49$ years $(47.5 \%)$. the average age were 30 years.

\begin{tabular}{|c|c|c|c|}
\hline $\begin{array}{l}\text { Mode of } \\
\text { transmission }\end{array}$ & $\begin{array}{l}\text { Correct } \\
\text { answer }\end{array}$ & $\begin{array}{l}\text { Incorrect } \\
\text { answer }\end{array}$ & $\begin{array}{l}\text { Do not } \\
\text { know }\end{array}$ \\
\hline Sexual contact & $80 \%$ & $18 \%$ & $2 \%$ \\
\hline Infected syringe & $73 \%$ & $22 \%$ & $5 \%$ \\
\hline Blood & $70 \%$ & $23(\%$ & $6 \%$ \\
\hline Mother to baby & $60 \%$ & $26 \%$ & $14 \%$ \\
\hline Mosquito & $8 \%$ & $35 \%$ & $57 \%$ \\
\hline Kissing & $47 \%$ & $29 \%$ & $24 \%$ \\
\hline Normal contact & $62 \%$ & $18 \%$ & $20 \%$ \\
\hline
\end{tabular}

Eighty percent patients knew that AIDS could be transmitted through the sexual contact followed by other corrected response like infected syringe $73 \%$, blood $70 \%$, and mother to baby $60 \%$, kissing $47 \%$ and mosquito bite $8 \%$ (Table 2).

Table 3. Sexual Behavior of Studied Population $(\mathrm{N}=208)$

\begin{tabular}{|l|l|r|}
\hline \multicolumn{2}{|l|}{ Sexual behavior } & \multicolumn{1}{l|}{ Frequency } \\
\hline \multirow{3}{*}{$\begin{array}{l}\text { Use of } \\
\text { Condom }\end{array}$} & Never use & $104(51 \%)$ \\
\cline { 2 - 3 } & Some times & $47(23 \%)$ \\
\cline { 2 - 3 } & Always & $53(26 \%)$ \\
\hline \multirow{3}{*}{$\begin{array}{l}\text { Types of } \\
\text { sexual partner }\end{array}$} & Friends & $2(1 \%)$ \\
\cline { 2 - 3 } & Prostitute & $43(21 \%)$ \\
\cline { 2 - 3 } & Others & $10(5 \%)$ \\
\hline \multirow{3}{*}{$\begin{array}{l}\text { No. of } \\
\text { sexual partners }\end{array}$} & Only one & $130(64 \%)$ \\
\cline { 2 - 3 } & 2-4 partners & $49(24 \%)$ \\
\cline { 2 - 3 } & > Four & $25(12 \%)$ \\
\hline
\end{tabular}

Among 208 respondents, 3 were children and they did not have exposed to sex. Majority of 104 $(51 \%)$ had never used condom. Fifty-three (26\%) respondents always used condom and $47(23 \%)$ did not use condom had visit to sex worker. A large number $43(21 \%)$ had prostitute as sexual partner. Two $(1 \%)$ had sexual relationship with their friends and $10(5 \%)$ had sexual relationship to others. Majority of $130(64 \%)$ were strict in single sexual partner. Forty-nine (24\%) had 2 to 4 sexual partners and $24(12 \%)$ had more than 4 sexual partners (Table 3). 


\begin{tabular}{|c|c|c|c|}
\hline Age group & Male & Female & Total \\
\hline $0-14$ yrs & $1(16.7 \%)$ & $2(16.7 \%)$ & $3(16.5 \%)$ \\
\hline $15-29 \mathrm{yrs}$ & $0(0)$ & $3(25.0 \%)$ & $3(16.5 \%)$ \\
\hline $30-49$ yrs & $4(66.6 \%)$ & $7(58.4 \%)$ & $11(61.5 \%)$ \\
\hline$\geq 50 \mathrm{yrs}$ & $1(16.7 \%)$ & $0(0)$ & $1(5.5 \%)$ \\
\hline Total & $6(100 \%)$ & $12(100 \%)$ & $18(100 \%)$ \\
\hline
\end{tabular}

Distribution of HIV sero-positive patients is shown in Table 4.

\begin{tabular}{|l|r|}
\hline \multicolumn{2}{|l|}{ Table 5. Laboratory Diagnosed STIs } \\
\hline Types of STI & Positive cases \\
\hline Syphilis : N=172 & $3(2 \%)$ \\
\hline Gonorrhoea: N=104 & $0(0 \%)$ \\
\hline Trichomonasis: N=104 & $10(10 \%)$ \\
\hline Bacterial Vaginosis: N=104 & $15(14 \%)$ \\
\hline Candidiasis: N=99 & $23(23 \%)$ \\
\hline
\end{tabular}

Based on clinical finding 40 (19\%) had different STI. The prevalence of vaginal candidiasis, bacterial vagionosis, trichomonasis and Syphilis was $23 \%$, $14 \% 10 \%, 2 \%$ respectively, but none of cases was positive for gonorrhea (Table 5).

Table 6. Correlation of HIV with Other STIS Syndrome

\begin{tabular}{|c|c|c|c|c|}
\hline \multirow{2}{*}{$\begin{array}{l}\text { HIV } \\
\text { Status }\end{array}$} & \multicolumn{3}{|c|}{ STI Status } & \multirow{2}{*}{$\begin{array}{l}\text { Chi- } \\
\text { square } \\
\text { value }\end{array}$} \\
\hline & Positive & Negative & Total & \\
\hline Positive & 12 & 6 & 18 & \multirow{3}{*}{$\begin{array}{c}30.9 \\
(P< \\
0.01)\end{array}$} \\
\hline Negative & 26 & 164 & 190 & \\
\hline Total & 38 & 170 & 208 & \\
\hline
\end{tabular}

As the Chi-square value obtained by cross tabulating with HIV/ other STI co-infected patients is $30.9(P<0.01)$. The HIV acquiring is highly associated with STIs (Table 6).

\section{DISCUSSION}

The high proportions of migrants were 15-29 years age group and most of them were female. In contrast to our study findings, a study done on
Eastern Nepal; the average age of migrant workers were 22.5 years and majority of them were between 15-35 years of age. ${ }^{9}$ The large proportion of HIV positive population was 30-49 years in the study, the age group with the highest population was wives of migrant. This data suggest that most of the people of this region leave their home town to earn money as migrant laborers at this age. Male migrant may engage of having sexual relationship with multiple partners and prostitutes due to loneliness need for intimacy and sex. There they acquire HIV infection and transmit the infection to their innocent homemakers during their short visit to home. Other studies also documented that the people of this age group are more susceptibility to HIV infection. Data of National centre for AIDS and STD control (NCASC) shows that 77.6 $\%$ HIV positive people are in the age group 21-30. ${ }^{10}$ The large proportion of HIV positive population was 26- 35 years, the age group with the highest population was migrants. This indicates that though age is an important determinant of HIV infection, migration women is also crucial factor in the spread of HIV in all age groups. ${ }^{11}$

This study found that migrant labor had good knowledge on HIVIAIDS. But a significant number had the misconception that one could contract HIV through mosquito bites and kissing. Almost $70 \%$ respondents fall under the categories of good knowledge, while only $15 \%$ respondents were ranked as poor knowledge. This finding was supported by study awareness and HIV risk behaviours among migrant workers in relation to HIVIAIDS- a study from eastern Nepal, in which also migrants were aware regarding the transmission of HIVIAIDS viz; unprotected sex $(92.7 \%)$, unscreened blood $(80.5 \%)$, infected syringe $(75.6 \%)$. The commonest misconceptions were found to be; through mosquito bite (53.5\%) and through normal contact were nearly $30 \%{ }^{12}$

Sexual behavior of patients increases the risk of HIV transmission. Highest proportion (51\%) were never used condom, $47 \%$ used condoms but they ignored to use condom, when they had drunk 
alcohol. which might made them transmission and acquiring of HIV. A large number 43(21\%) had prostitute as sexual partner. Most of the male migrant frequently visited prostitute when they were in India. The practices of prostitute sex among male migrant was also interesting finding. They revealed one secret that they generally had unprotected sex with prostitute because they were alone (wife at home) for a long time in India and feel thought their wife and children then drunk alcohol visited prostitute for sexual satisfaction. One participant made a statement "Male migrant in India generally to gathered and drunk alcohol, then planed to visit prostitute and may had group sex." Female were strict within the single sex partner but few cases were involving in commercial sexual worker because they had already lost their husband.

Among HIVIAIDS other STIs co-infected patients, both male and female were found in equally infected. HIVISTI co- infected patients belong to above 30 years. Migrants aged 30 years or younger were greater risk of HIV infection than those who were older. Another study showed that HIV infected migrant women were significantly older (mean=34.4 years).

Table 4 and 6 presents, gender had no relation to acquiring HIV/ STIs $(p=0.105)$. As the Chi-square value obtained by cross tabulating with HIV/ other STI co-infected patients is $30.9(P<0.01)$. The HIV acquiring is highly associated with STIs. STD syndromes were highly significant relation to acquiring HIV Infection. STIS increases the risk of acquiring HIV infection, HIV can easily pass through breaks in the skin caused by genital ulcers or it is transmitted in the same way as other STIs. ${ }^{11}$

\section{CONCLUSION}

The result shows that migrant people are at high risk of infection. HIV infection was higher among aged 31 years, at this age people went to India for earning and import HIV infection to their wife during their short visit to home. The HIV infection was significantly associated to curable STDs. Migrant people still confused about transmission of HIV/ AIDS. The prevalence of HIV and curable STDs are alarmingly high and emphasize the urgent need for interventions aimed at combating the spread of HIV and STDs among women in general and migrant or wives of migrant in particular. Such interventions should address social and economic factors promoting the spread of HIV. There is an urgent need for provision of services to treat STDs, VCT services will be strengthened and strictly launched to migrant and their wives. Education and empowerment programmes are need that will promote condom use among migrants. In the longer term, steps must be taken to address the social and economic pressures that migrant face.

\section{ACKNOWLEDGEMENTS}

Finance for the survey was provided by University Grant Commission. Specimen was collected from Nepal National Social-welfare Association, Mahakali Zonal Hospital. HIVIAIDS camp at Jhalari VDC and Dodhara VDC. Laboratory facilities were provided by Department of Microbiology, Shree Siddhanath Science Campus, Mahendranagar, Kanchapur, Nepal.

\section{REFERENCES}

1. Chander A, Pahawa VK. Seroprevalence of HIV1/ HIV2 infection in Bhairawa, Western Nepal: A hospital base study. J Nepal Health Res Counc 2004;2:51-4.

2. WHO. TB/HIV facts 2009. Available from http:// www.who.int / tb /challenges / hiv/factsheet_ hivtb_2009update.pdf. Retrieved on 21 ${ }^{\text {st }}$ April, 2010. (Cited 2010 May 21).

3. National Centre of AIDS and STI Control. Cumulative HIVIAIDS Situation of Nepal (Facts and Figure) 2009.

4. SAARC TB and HIVIAIDS centre. HIV and AIDS in the SAARC region an update $2008 ; 51-8$.

5. Mozes A. Nepal at the precipice of major AIDS crisis 2006. http:// gogle.yahoo.com/bin/queryp 
6. National Center for AIDS and STD Control Nepal. National HIVIAIDS Strategy (2002-2006) Nepal. Ministry of Health. 2003.

7. WHO. Regional Strategic Plan on HIV/TB SEA/TB/ 261.

8. Cheesbrough M. Medical Laboratory Manual for Tropical Countries. Volume II, $2^{\text {nd }}$ ed. USA... Cambridge University Press 2006;129-390.

9. Usman A, et al. Awareness and high risk behaviours among migrant workers in relation to HIVIAIDS - $A$ study from Eastern Nepal. SAARC J Tuber Lung Dis HIVI AIDS 2006;3:5-12.
10. National Center for AIDS and STD Control Nepal. Country Report on HIVIAIDS 2008.

11. Zuma K, Gouws, Willams B, Lurie M. Risk factors for HIV infection among women in Carletonville, South Africa: migration, demography and sexually transmitted diseases. Int J STD AIDS 2003;14:81417. 